\title{
Laccase: Microbial Sources, Production, Purification, and Potential Biotechnological Applications
}

\author{
Shraddha, Ravi Shekher, Simran Sehgal, Mohit Kamthania, and Ajay Kumar \\ Department of Biotechnology, Institute of Biomedical Education \& Research, Mangalayatan University, Aligarh 202001, India \\ Correspondence should be addressed to Ajay Kumar, ajaymtech@gmail.com
}

Received 25 January 2011; Revised 30 March 2011; Accepted 16 April 2011

Academic Editor: Alane Beatriz Vermelho

Copyright () 2011 Shraddha et al. This is an open access article distributed under the Creative Commons Attribution License, which permits unrestricted use, distribution, and reproduction in any medium, provided the original work is properly cited.

Laccase belongs to the blue multicopper oxidases and participates in cross-linking of monomers, degradation of polymers, and ring cleavage of aromatic compounds. It is widely distributed in higher plants and fungi. It is present in Ascomycetes, Deuteromycetes and Basidiomycetes and abundant in lignin-degrading white-rot fungi. It is also used in the synthesis of organic substance, where typical substrates are amines and phenols, the reaction products are dimers and oligomers derived from the coupling of reactive radical intermediates. In the recent years, these enzymes have gained application in the field of textile, pulp and paper, and food industry. Recently, it is also used in the design of biosensors, biofuel cells, as a medical diagnostics tool and bioremediation agent to clean up herbicides, pesticides and certain explosives in soil. Laccases have received attention of researchers in the last few decades due to their ability to oxidize both phenolic and nonphenolic lignin-related compounds as well as highly recalcitrant environmental pollutants. It has been identified as the principal enzyme associated with cuticular hardening in insects. Two main forms have been found: laccase-1 and laccase-2. This paper reviews the occurrence, mode of action, general properties, production, applications, and immobilization of laccases within different industrial fields.

\section{Introduction}

In the recent years, enzymes have gained great importance in Industries; laccases are one among them which are widely present in the nature. Laccases are the oldest and most studied enzymatic systems [1]. These enzymes contain 15$30 \%$ carbohydrate and have a molecule mass of $60-90 \mathrm{kDa}$. These are copper containing 1,4-benzenediol: oxygen oxidoreductases (EC 1.10.3.2) found in higher plants and microorganisms. These are glycosylated polyphenol oxidases that contain 4 copper ions per molecule that carry out 1 electron oxidation of phenolic and its related compound and reduce oxygen to water $[2,3]$. When substrate is oxidized by a laccase, it loses a single electron and usually forms a free radical which may undergo further oxidation or nonenzymatic reactions including hydration, disproportionation, and polymerization [4]. These enzymes are polymeric and generally contain 1 each of type 1 , type 2 , and type 3 copper centre/subunit where the type 2 and type 3 are close together forming a trinuclear copper cluster.
Laccases are widely distributed in higher plants, bacteria, fungi, and insects. In plants, laccases are found in cabbages, turnip, potatoes, pears, apples, and other vegetables. They have been isolated from Ascomyceteous, Deuteromycteous and Basidiomycetous fungi to which more than 60 fungal strains belong [3]. The white-rot Basidiomycetes fungi efficiently degrade the lignin in comparison to Ascomycetes and Deuteromycetes which oxidize phenolic compounds to give phenoxy radicals and quinines [5].

Laccases play an important role in food industry, paper and pulp industry, textile industry, synthetic chemistry, cosmetics, soil bioremediation and biodegradation of environmental phenolic pollutant and removal of endocrine disruptors [2]. These enzymes are used for pulp delignification, pesticide or insecticide degradation, organic synthesis [4], waste detoxification, textile dye transformation, food technological uses, and biosensor and analytical applications.

Recently laccases have been efficiently applied to nanobiotechnology due to their ability to catalyze electron transfer reactions without additional cofactor. The technique for 
the immobilization of biomolecule such as layer-by-layer, micropatterning, and self-assembled monolayer technique can be used for preserving the enzymatic activity of laccases.

\section{Sources of Laccases}

Laccase is generally found in higher plants and fungi but recently it was found in some bacteria such as S.lavendulae, S.cyaneus, and Marinomonas mediterranea [6-8]. In fungi, laccases appear more than the higher plants. Basidiomycetes such as Phanerochaete chrysosporium, Theiophora terrestris, and Lenzites, betulina [9], and white-rot fungi $[10,11]$ such as Phlebia radiate [12], Pleurotus ostreatus [13], and Trametes versicolour [14] also produce laccase. Many Trichoderma species such as $T$. atroviride, T. harzianum [15], and $T$. longibrachiatum [16] are the sources of laccases. Laccase from the Monocillium indicum was the first laccase to be characterized from Ascomycetes which shows peroxidase activity [8]. Pycnoporus cinnabarinus produces laccase as ligninolytic enzyme while Pycnoporus sanguineus produces laccase as phenol oxidase $[17,18]$. In plants, laccase plays a role in lignifications whereas in fungi it has been implicated in delignification, sporulation, pigment production, fruiting body formation, and plant pathogenesis [19, 20].

\section{Mechanism of Laccases}

The laccase catalysis occurs due to the reduction of one oxygen molecule to water accompanied with the oxidation of one electron with a wide range of aromatic compounds which includes polyphenol [21], methoxy-substituted monophenols, and aromatic amines [14]. Laccases contain 4 copper atoms termed $\mathrm{Cu} \mathrm{T} 1$ (where the reducing substrate binds) and trinuclear copper cluster T2/T3 (electron transfer from type I $\mathrm{Cu}$ to the type II $\mathrm{Cu}$ and type III $\mathrm{Cu}$ trinuclear cluster/reduction of oxygen to water at the trinuclear cluster) [3]. These four copper ions are classified into three categories: Type 1 (T1), Type 2 (T2) and Type 3 (T3). These three types can be distinguished by using UV/visible and electronic paramagnetic resonance (EPR) spectroscopy.

At oxidizing state, the Type $1 \mathrm{Cu}$ gives blue colour to the protein at an absorbance of $610 \mathrm{~nm}$ which is EPR detectable, Type $2 \mathrm{Cu}$ does not give colour but is EPR detectable, and Type $3 \mathrm{Cu}$ contains a pair of atoms in a binuclear conformation that give a weak absorbance in the near UV region but not detected by EPR signal [19]. The Type 2 copper and Type 3 copper form a trinuclear centre which is involved in the enzyme catalytic mechanism. The $\mathrm{O}_{2}$ molecule binds to the trinuclear cluster for asymmetric activation, and it is postulated that the $\mathrm{O}_{2}$ binding compartment appears to restrict the access of oxidizing agents. During steady state, laccase catalysis indicates that $\mathrm{O}_{2}$ reduction takes place [3]. Laccase operates as a battery and stores electrons from individual oxidation reactions to reduce molecular oxygen. Hence, the oxidation of four reducing substrate molecules is necessary for the complete reduction of molecular oxygen to water. When laccase oxidizes the substrate, free radicals are generated. The lignin degradation proceeded by phenoxy radical leads to oxidation at $\alpha$-carbon or cleavage of bond between $\alpha$-carbon and $\beta$-carbon. This oxidation results in an oxygen-centered free radical, which can be converted into a second enzyme-catalyzed reaction to quinone. The quinone and the free radicals can then undergo polymerization [19]. The organization of the copper sites in laccase is explained by the spectroscopic studies [22] which reveal that Type 2 copper coordinates two His- $\mathrm{N}$ and one oxygen atom as $\mathrm{OH}^{-}$ while each copper of Type 3 coordinates three His residues. Further, both T2 and T3 copper sites have open coordination positions towards the center of trinuclear cluster with the negative protein compartment [23].

The laccase-mediated catalysis can be extended to nonphenolic substrates by the insertion of mediators. Mediators are low-molecular-weight organic compounds that are oxidized by laccase. The highly active cation radicals oxidize the non-phenolic compounds that laccase alone cannot oxidize. The most common synthetic mediators are 1-hydroxy benzotriazole (HOBT), N-hydroxyphthalimide (NHPI), 2,2'azinobis-(3-ethylbenzthiazoline-6-sulfonate) (ABTS), and 3 hydroxyanthranilic acid $[14,24]$. In presence of ABTS oxygen uptake by laccase is faster than the HOBT.

\section{Properties of Laccase Enzyme}

Laccases are mainly monomeric, dimeric, and tetrameric glycoprotein. Glycosylation plays an important role in copper retention, thermal stability, susceptibility to proteolytic degradation, and secretion. Upon purification, laccase enzymes demonstrate considerable heterogeneity. Glycosylation content and composition of glycoprotein vary with growth medium composition.

\section{Production of Laccase}

Laccases are the enzymes which are secreted out in the medium extracellularey by several fungi [25] during the secondary metabolism but not all fungal species produce laccase such as Zygomycetes and Chytridiomycetes [26]. The literature describes the production of laccase by soil as well as some freshwater Ascomycetes species [27-31]. In addition to this, laccase production was also found in Gaeumannomyces graminis, Magnaporthe grisea, Ophiostoma novo-ulmi, Marginella, Melanocarpus albomyces, Monocillium indicum, Neurospora crassa, and Podospora anserina [8, 32-38].

Botryosphaeria produces a dimethoxyphenol oxidizing enzyme which is a true laccase [39]. The Ascomycetes species which participate in the plant biomass decay contain laccase genes which oxidize syringaldazine [40]. Cryptococcus neoformans is Basidiomycetes yeast which produces laccase and oxidizes phenols and aminophenol but is unable to oxidize tyrosine [1]. Only plasma membrane-bound multicopper oxidase of Saccharomyces cerevisiae shows homology with fungal laccase [41].

Basidiomycetes and Saprotrophic fungi are the most widely known species that produce substantial amount of laccase in changeable quantity [42]. In case of Pycnoporus cinnabarinus, laccase was the only ligninolytic enzyme which 
degrades lignin [17]. But the laccase producing capability of brown-rot fungi is not known, and no laccase has been purified. Recently it was found that brown-rot fungus Coniophora puteana [43] oxidizes the syringaldazine and supports the oxidation of ABTS in Laetiporus sulphureus [44]. Several factors influence laccase production such as type of cultivation (submerged or solid state), carbon limitation, and nitrogen source [45].

\section{Influence of Carbon and Nitrogen Source}

The organism grown in the defined medium contains $0.1 \% \mathrm{w} / \mathrm{v}$ yeast extract and $1 \%(\mathrm{w} / \mathrm{v})$ different carbon sources as well as nitrogen sources. Glucose, mannose, maltose, fructose, and lactose are the commonly used carbon sources. The excess glucose and sucrose reduce the production of laccase by obstructing the initiation. This problem of production of enzyme can be improved by using polymeric substrates like cellulose [43]. Yeast extract, peptone, urea, $(\mathrm{NH} 4)_{2} \mathrm{SO}_{4}$, and $\mathrm{NaNO}_{3}$ are the commonly used nitrogen sources. Laccase production is triggered by nitrogen depletion [46] but some nitrogen strains do not affect the enzyme activity [47]. Some studies show that the elevated laccase activity was achieved by using low carbon-to-nitrogen ratio [48] while others show that it was achieved at high carbon-to-nitrogen ratio [49].

\section{Influence of Temperature}

The effect of temperature is limited in case of laccase production. The optimal temperature of laccase differs greatly from one strain to another. It has been found that $25^{\circ} \mathrm{C}$ is the optimal temperature for laccase production in presence of light, but, in case of dark, the optimal temperature is $30^{\circ} \mathrm{C}$ [19]. The optimum temperature range for laccase production is between $25^{\circ} \mathrm{C}$ and $30^{\circ} \mathrm{C}$ [50]. Farnet et al. [51] found that preincubation of enzymes at $40^{\circ} \mathrm{C}$ and $50^{\circ} \mathrm{C}$ greatly increased laccase activity. The laccase from $P$. ostreatus is almost fully active in the temperature range of $40^{\circ} \mathrm{C}-$ $60^{\circ} \mathrm{C}$, with maximum activity at $50^{\circ} \mathrm{C}$. The activity remains unaltered after prolonged incubation at $40^{\circ} \mathrm{C}$ for more than $4 \mathrm{~h}$ [52]. Nyanhongo et al. [53] showed that laccase produced by $T$. modesta was fully active at $50^{\circ} \mathrm{C}$ and was very stable at $40^{\circ} \mathrm{C}$ but half-life decreased to $120 \mathrm{~min}$ at higher temperature $\left(60^{\circ} \mathrm{C}\right)$.

\section{Influence of $\mathbf{p H}$}

The effect of $\mathrm{pH}$ is limited in case of laccase production [19]. The optimum value of $\mathrm{pH}$ varies according to the substrate because different substrate causes different reaction for laccases. Many reports suggested that the bell-shaped profile occurs in case of laccase activity. At high $\mathrm{pH}$ value, the potential difference between the phenolic substrate and the T1 copper can increase the substrate oxidation while the hydroxide anion $\left(\mathrm{OH}^{-}\right)$binds to the T2/T3 copper centre. These effects help us in determining the optimum value of $\mathrm{pH}$ for laccase enzyme [54]. Cordi et al. [55] use syringaldazine as a substrate and determine the effect of $\mathrm{pH}$ on enzyme activity in the range of 3.0-8.0. The optimum $\mathrm{pH}$ for L1 (isozyme of laccase) was 4.0 whereas the optimum $\mathrm{pH}$ for L2 was 5.0. Han et al. [56] extracted laccase from Trametes versicolour which showed high enzyme activity at broad range of $\mathrm{pH}$ and temperature ranges but the optimum activity was found at $\mathrm{pH} 3.0$ and $50^{\circ} \mathrm{C}$ temperature. Laccase extracted from Stereum ostrea showed the highest activity at pH 6.0 and $40^{\circ} \mathrm{C}$ temperature [57]. When fungi are grown in the medium of $\mathrm{pH} 5.0$, the laccase will produce in excess but most studies show that $\mathrm{pH}$ between 4.5 and 6.0 is suitable for enzyme production [19].

\section{Influence of Agitator}

Agitation is another factor which affects laccase production. Hess et al. [58] found that mycelia are damaged when fungus is grown in the stirred tank reactor and laccase production by Trametes multicolour is considerably decreased. Mohorčič et al. [59] found that cultivation of white-rot fungus Bjerkandera adusta in a stirred tank reactor with very low activities was attained. Tavares et al. [60] observed that agitation did not play any role in the production of laccase by $T$. versicolour.

\section{Influence of Inducer}

Laccase production has been seen to be highly dependent on fungus cultivation [61]. During secondary metabolic phase, ligninolytic systems are activated and triggered by nitrogen concentration [49]. Laccases are generally produced in low concentrations by laccase-producing fungi [39], but higher concentrations were obtained with the addition of various supplements such as xenobiotic compound to media $[62,63]$. The addition of aromatic compounds such as 2,5xylidine, lignin, and veratryl alcohol is known to increase and induce laccase activity [63, 64]. Veratryl alcohol is an aromatic compound; its addition to cultivation media results in an increase of laccase production [65]. The addition of 2,5-xylidine after $24 \mathrm{~h}$ of cultivation gave the highest induction of laccase activity and increased laccase activity ninefold. At higher concentrations the 2,5-xylidine had a reducing effect due to toxicity [17]. The promoter region encoding for laccase contains various recognition sites that are specific for xenobiotics and heavy metals [66]; they bind to the recognition sites and induce laccase production. The addition of inducer increases the concentration of a specific laccase enzyme [67]. Lee et al. [62] found that alcohol enhanced laccase activity more in comparison to xylidine. This is a very economical way to enhance laccase production. Cellobiose increase laccase activity by profusing branch in certain Trametes species [68]. Low concentrations of $\mathrm{Cu}^{+2}$ to the cultivation media increases the laccase production 50 times in comparison to basal medium $[13,69]$. A new basidiomycete, Trametes sp. 420, produced laccase in glucose medium and in cellobiose medium with induction by $0.5 \mathrm{mM}$ and $6 \mathrm{mM}$ o-toluidine [70]. D'Souza-Ticlo et al. [71] performed various experiments to determine the effect of inhibitor on the activity of Lac-II in the presence of sodium 
azide, SDS, and mercaptoethanol. They found that 32-37\% activity of Lac-II was inhibited in the presence of Sn, Ag, and $\mathrm{Hg}$ while $56 \%$ and $48 \%$ Lac-II activity was inhibited in the presence of $\mathrm{Cr}$ and $\mathrm{W}$, respectively. Dubé et al. [72] found that $5 \mathrm{Mm}$ EDTA inhibits the total laccase activity.

\section{Type of Cultivation}

Submerged and solid-state modes of fermentation are used intensely for the production of laccase. Wild-type filamentous fungi are used for large-scale production of laccase in different cultivation techniques.

11.1. Submerged Fermentation. Submerged fermentation involves the nurturing of microorganisms in high oxygen concentrated liquid nutrient medium. Viscosity of broth is the major problem associated with the fungal submerged fermentations. When fungal cell grows, mycelium is formed which hinders impeller action, due to this limitation occuring in oxygen and mass transfer. For dealing with this problem, different strategies have been employed. Bioreactor operates in continuous manner for obtaining high efficiency. In this Trametes versicolour is employed which decolorizes the synthetic dye, and for this purpose pulsed system has been developed [73-77]. Broth viscosity, oxygen, and mass transfer problems are also solved by cell immobilization. Luke and Burton [78] reported that continuous laccase production takes place without enzyme deactivation for a period of 4 months due to the immobilization of the Neurospora crassa on membrane. For bioremediation of pentachlorophenol (PCP) and 2,4-dichlorophenol (2,4 DCP), nylon mesh is used for comparing the free cell culture of $T$. versicolour with immobilized cultures. Couto et al. and Sedarati et al. investigated that, in fixed bed bioreactors, stainless steel showed the highest laccase activity among different synthetic materials which were used as carriers for the immobilization of Trametes hirsute [79-81]. The most effective way of producing laccase is Fed-batch operation through which the highest laccase activity can be obtained.

11.2. Solid-State Fermentation. SSF is suitable for the production of enzymes by using natural substrates such as agricultural residues because they mimic the conditions under which the fungi grow naturally [82-85]. The lignin, cellulose and hemicelluloses are rich in sugar and promote fungal growth in fermentor and make the process more economical [86]. The major drawback is the bioreactor design in which heat and mass transfer is limited. Different bioreactor configurations have been studied for laccase production such as immersion configuration, expanded bed, tray, inert (nylon) and noninert support (barley bran) in which tray configuration gave the best response [87]. A tray and immersion configuration is compared for laccase production by using grape seeds and orange peel as substrate $[88,89]$.

Laccase production by both solid-state and submerged fermentation is higher in case of rice bran than other substrates. The rice bran inductive capability is based on the phenolic compounds such as ferulic acid, and vanillic acid which induce the laccase production [90]. Many agricultural wastes such as grape seeds, grape stalks, barley bran [91], cotton stalk, molasses waste water [92] and wheat bran [93] are also used as substrate for laccase production. However, laccase production in both solid-state and submerged fermentation did not reach up to the maximum level; that is why prolonged cultivation is required.

\section{Purification of Laccase}

Ammonium sulphate is being commonly used for the enzyme purification for many years. But researchers have found much more efficient methodologies such as protein precipitation by ammonium sulphate, anion exchange chromatography, desalt/buffer exchange of protein, and gel filtration chromatography. Single-step laccase purification from Neurospora crassa takes place by using celite chromatography and 54 fold purification was obtained with specific activity of $333 \mathrm{U} \mathrm{mg}^{-1}$ [94]. Laccase from LLP13 was first purified with column chromatography and then purified with gel filtration $[10,11]$. Laccase from T. versicolour is purified by using ethanol precipitation, DEAE-Sepharose, PhenylSepharose and Sephadex G-100 chromatography which is a single monomeric laccase with a specific activity of $91,443 \mathrm{U} \mathrm{mg}^{-1}$ [58]. Laccase from T. versicolour is purified with Ion Exchange chromatography followed by gel filtration with specific activity of $101 \mathrm{U} \mathrm{mL}^{-1}$ and 34.8 -fold purification [55]. Laccase from Stereum ostrea is purified with ammonium sulphate followed by Sephadex G-100 column chromatography with 70-fold purification [9]. Laccase from fruiting bodies is purified with ammonium sulphate precipitation with $40-70 \%$ saturation and DEAE cellulose chromatography then 1.34 and 3.07 fold purification is obtained respectively [95].

\section{Applications of Laccase}

Laccase is important because it oxidizes both the toxic and nontoxic substrates. It is utilized in textile industry, food processing industry, wood processing industry, pharmaceutical industry, and chemical industry. This enzyme is very specific, ecologically sustainable and a proficient catalyst. Applications of laccase are as follows.

13.1. Dye Decolorization. Textile industry utilizes large volume of water and chemicals for wet processing. These chemicals range from inorganic compounds to organic compounds. The chemical structure of dyes provides a resistance to fading when exposed to light, water, and other chemicals. Laccase degrades dye; that is why laccase-based processes have been developed which include synthetic dyes and are being used in the industry nowadays $[96,97]$.

Blánquez et al. [98] used T. versicolour in the form of pellets to treat a black liquors discharge for detoxifying and reducing the colour, aromatic compounds, and chemical oxygen demand (COD). They found that colour and aromatic compounds were reduced up to $70-80 \%$ and COD 
was reduced up to $60 \%$. They concluded that T. versicolour is able to produce laccase. $T$. versicolour completely decolorizes the Amaranth, Tropaeolin O, Reactive Blue 15, Congo Red, and Reactive Black 5 with no dye sorption while it partially decolorizes Brilliant Red 3G-P, Brilliant Yellow 3B-A and Remazol Brilliant Blue $\mathrm{R}$ with some dye sorption. They found that after decolourization, toxicity of few dyes remained the same while some became nontoxic [99]. Laccase-based hair dyes are less irritant and easier to handle than conventional hair dyes because laccases replace $\mathrm{H}_{2} \mathrm{O}_{2}$ in the dye formulation [100]. Laccase are also used in dechlorination process. Xylidine is a laccase inducer which increases dechlorination activity due to which dissolved oxygen concentration is reduced [101]. Romero et al. [77] found that bacteria $S$. maltophilia decolorizes some synthetic dyes (methylene blue, methyl green, toluidine blue, Congo red, methyl orange, and pink) as well as the industrial effluent.

13.2. Bioremediation and Biodegradation. Due to rapid industrialization and extensive use of pesticides for better agricultural productivity, contamination of soil, water, and air take place which is a serious environmental problem of today. Polychlorinated biphenyls (PCB), benzene, toluene, ethyl benzene, xylene (BTEX), polycyclic aromatic hydrocarbons (PAH), pentachlorophenol (PCP), 1,1,1-trichloro2,2-bis (4-chlorophenyl) ethane (DDT), and trinitrotoluene (TNT) are the substances which are known for their carcinogenic as well as mutagenic effect and are persistent in the environment. Fungi renovate a wide variety of hazardous chemicals; that is why the researcher's interest is generated in them [102].

T. versicolour is used for the bioremediation of atrazine in soil with low moisture and organic contents that are normally found in semiarid and Mediterranean-like ecosystems [103]. Keum and Li [104] obtained laccase from T. versicolour and Pleurotus ostreatus for the degradation of PCBs as well as phenol and found as chlorination increases, degradation rate decreases and concluded that 3-hydroxy biphenyl was more resistant to laccase degradation than 2- or 4-hydroxy analogues. After five days of incubation, when glucose and fructose were used as a cosubstrate than $71 \%$ of p-hydroxy benzoic acid and $56 \%$ of protocatechuic acid were degraded [105].

Laccase obtained from T. villosa remediates the soil by degrading 2,4-DCP (2,4-dichlorophenol). An experiment was performed by Ahm in which he took 2 types of soil: in soil 1, both free and immobilized laccase remove $100 \%$ of 2,4-DCP (without regard of moisture content). In soil 2, immobilized laccase removed more 2,4-DCP (about 95\%) than free enzyme $(55 \%, 75 \%$, and $90 \%$, at $30 \%, 55 \%, 100 \%$ maximum water holding capacity) [106]. Cerrena unicolosr produces laccase in the low nitrogen medium which has the capability of reducing lignin content from sugarcane bagasse up to $36 \%$ within $24 \mathrm{~h}$ at $30^{\circ} \mathrm{C}$ [71].

13.3. Paper and Pulp Industry. Chlorine and oxygen-based chemical oxidants are used for the separation and degradation of lignin which is required for the preparation of paper at industrial level. But some problems such as recycling, cost, and toxicity remain unsolved. However, in the existing bleaching process, LMS could be easily implemented because it leads to a partial replacement of $\mathrm{ClO}_{2}$ in pulp mills [54].

13.4. Food Processing Industry. In food industry, laccase is used for the elimination of undesirable phenolic compound in baking, juice processing, wine stabilization, and bioremediation of waste water [2]. Laccase improves not only the functionality but also the sensory properties [107]. In beer industry, laccase not only provides stability but also increases the shelf life of beer. In beer, haze formation takes place which is stimulated by the naturally present proanthocyanidins polyphenol and is referred to as chill haze. At room temperature or above, warming of beer can redissolve the complex. After certain periods of time, phenolic rings are replaced by the sulphydryl group and permanent haze is formed which cannot be redissolved. For polyphenol oxidation, laccase has been used which is capable of removing the excess oxygen and also due to which the shelf life of beer increases [108, 109]. For making a fruit juice stable, laccase is commonly used. Phenol compounds and their oxidative products present naturally in the fruit juice give colour and taste to the juice. Colour and aroma change when polymerization and oxidation of phenolic and polyphenol take place. These changes are due to the high concentration of polyphenol and referred to as enzymatic darkening [110]. Laccase treatment removes phenol as well as substrate-enzyme complex by the help of membrane filtration, and colour stability is achieved, although turbidity is present. Laccase treatment is more effective in comparison to conventional methods. For improving the texture, volume, flavor and freshness of bread, wide range of enzymes are used. When laccase is added to the dough, strength of gluten structures in dough and baked products is improved: product volume increases, crumb structure improves, and softness of baked products takes place. Due to the laccase addition, stickiness decreases, strength and stability increase and the ability of machine is also improved which can also seen by using a low-quality flour [109]. At crushing and pressing stage, the high concentration of phenolic and polyphenolic compound play an important role in the wine production. The high concentration of polyphenol obtained from the stems, seeds and skins which depends on the grape variety and vinification conditions contributes to of colour and astringency [111]. Due to the complex event, polyphenol oxidation occurs in musts and wines resulting in the increase in colour and flavour change which is referred to as maderization [108]. Catalytic factors, polyphenol removal, clarification, polyvinylpolypyrrolidone (PVPP), and high doses of sulfur dioxide are utilized to prevent maderization. Minussi et al. found that polyphenol removal is selective and results in undesirable organoleptic characteristics and concluded that laccase treatment is feasible, increasing storability and reducing processing costs [111].

13.5. Other Applications. Laccase not only is used in food industry, paper and pulp industry, textile industry but also has 
other applications. In traditional system, PVPP is used for the removal of excess polyphenol which has low biodegradability and creates problems in wastewater treatment [109]. Laccase has the ability to decrease odour arising from the garbage disposal sites, livestock farms and pulp mills. Since laccases catalyze the electron transfer reactions without additional cofactors, they can also be used as biosensors to detect various phenolic compounds, oxygen, and azide. As biosensor, laccase can detect morphine, codeine, catecholamine, estimate phenol or other enzymes in fruit juice and plant flavonoid. Recently, laccase has been used as a biocatalyst for the synthesis of organic substance as well as in the design of biofuel cell [54]. For the bioremediation of food industry wastewater, laccase has been utilized. In bioremediation process, contaminants are biotransformed to their original status which has no bad effects on the environment [112]. Large amount of polyphenol is present in the beer factory wastewater which is dark brown in colour and degraded by the white-rot fungus Coriolopsis gallica [113]. Laccase produced from Trametes sp. bioremediates the distillery wastewater generated from the sugarcane molasses fermentation with high content of organic matter [114]. Olive mill wastewater is bioremediated by the help of immobilized laccase which is beneficial for the cultivation of fungi for laccase production [109]. Many countries pose some rules and regulation for the pollutants which includes phenols and amines [115].

13.6. Laccase Function in Insects. Laccase has been found in the cuticles of many insect species [116, 117] and is involved in cuticle sclerotization $[118,119]$. Laccases oxidizes catechols in the cuticle to their corresponding quinones, which catalyzes protein cross-linking reactions. In several holometabolous insects, laccase has been identified as the principal enzyme associated with cuticular hardening [120123]. The insect laccase is a long amino-terminal sequence characterized by a unique domain consisting of several conserved cysteine, aromatic, and charged residues. In recent years, cloning of insect laccase genes has been performed $[120,121,124]$ and two main forms have been found: laccase- 1 and laccase- 2 [120, 121, 125, 126]. Laccase-1 was found to be expressed in the midgut, Malpighian tubules $[121,126,127]$ and fat body as well as the epidermis of the tobacco hornworm, Manduca sexta, and may oxidize toxic compounds ingested by the insect [121]. On the other hand, laccase-2 was involved in cuticle tanning of the red flour beetle, Tribolium castaneum [120]. Recently, a laccase in the salivary glands of $N$. cincticeps was identified, which is secreted in watery saliva, by using biochemical and histochemical approaches [128]. A possible function of salivary laccase (diphenoloxidase) is in the enhancement of the oxidative gelling occurring in the stylet sheath by a quinone-tanning reaction [129] and rapid oxidization of potentially toxic monolignols to nontoxic polymers during feeding [128].

\section{Laccase Immobilization}

When enzyme is immobilized, it becomes more vigorous and resistant to alteration in environment which allows easy recovery and reuse of enzyme for multiple purposes. That is why researchers are moving towards the efficient methods of immobilization which influence the properties of the biocatalyst. Laccase immobilization has been studied with a wide range of different immobilization methods and substrates.

Laccase produced by Trametes versicolour is immobilized on silica which is chemically modified with imidazole groups and Amberlite IRA-400. Glass-ceramic is chemically modified by carbodiimide/glutaraldehyde as well as aminopropropyltriethoxysilane/glutaraldehyde, and montmorillonite is modified by aminopropyltriethoxysilane/glutaraldehyde which was used in the decolorization of textile dyes [130]. Laccase can be immobilized on different pyrolytic graphite (best support), ceramics supports and on a carbon fiber electrode where it acts as biosensor. At the 12th day, maximum laccase activity 40,774.0 $\mathrm{U} \mathrm{L}^{-1}$ was achieved [131]. An optical biosensor is fabricated by using stacked films for the detection of phenolic compounds; 3-methyl-2-benzothiazolinone hydrazone $(\mathrm{MBTH})$ was immobilized on a silicate film and laccase on a chitosan film [132].

\section{Conclusion}

Laccases are the versatile enzymes which catalyze oxidation reactions coupled to four-electron reduction of molecular oxygen to water. They are multicopper enzymes which are widely distributed in higher plants and fungi. They are capable of degrading lignin and are present abundantly in many white-rot fungi. They decolorize and detoxify the industrial effluents and help in wastewater treatment. They act on both phenolic and nonphenolic lignin-related compounds as well as highly recalcitrant environmental pollutants which help researchers to put them in various biotechnological applications. They can be effectively used in paper and pulp industries, textile industries, xenobiotic degradation, and bioremediation and act as biosensor. Laccase has been applied to nanobiotechnology which is an increasing research field and catalyzes electron transfer reactions without additional cofactors. Recently several techniques have been developed for the immobilization of biomolecule such as micropatterning, self-assembled monolayer, and layer-bylayer technique which immobilize laccase and preserve their enzymatic activity. Hence laccase is receiving much attention of researchers around the globe.

\section{Future Trends and Perspectives}

This paper shows that laccase has a great potential application in several areas of food industry. However, one of the limitations for the large-scale application of laccase is the lack of capacity to produce large volumes of highly active enzyme at an affordable cost. The use of inexpensive sources for laccase production is being explored in recent times. In this regard, an emerging field in management of industrial wastewater is exploiting its nutritive potential for production of laccase. Besides solid wastes, wastewater from the food processing industry is particularly promising for that. 


\section{Acknowledgments}

The authors are grateful to Professor Ashok Kumar (Dean, I.B.M.E.R, Mangalayatan University Aligarh, India) for providing necessary facilities and encouragement. They are also thankful to all faculty members of the Institute of Biomedical Education and Research, Mangalayatan University Aligarh, India for their generous help and suggestions during the paper preparation.

\section{References}

[1] P. R. Williamson, "Biochemical and molecular characterization of the diphenol oxidase of cryptococcus neoformans: identification as a laccase," Journal of Bacteriology, vol. 176, no. 3, pp. 656-664, 1994.

[2] S. R. Couto and J. L. Toca Herrera, "Industrial and biotechnological applications of laccases: a review," Biotechnology Advances, vol. 24, no. 5, pp. 500-513, 2006.

[3] L. Gianfreda, F. Xu, and J. M. Bollag, "Laccases: a useful group of oxidoreductive enzymes," Bioremediation Journal, vol. 3, no. 1, pp. 1-25, 1999.

[4] J. Faccelo and O. Cruz, Banana skin: a novel material for a low-cost production of laccase, M.S. thesis, Universitat Rovira I Virgili, 2008.

[5] C. Eggert, U. Temp, J. F. D. Dean, and K. E. L. Eriksson, "A fungal metabolite mediates degradation of non-phenolic lignin structures and synthetic lignin by laccase," FEBS Letters, vol. 391, no. 1-2, pp. 144-148, 1996.

[6] M. E. Arias, M. Arenas, J. Rodr íguez, J. Soliveri, A. S. Ball, and M. Hernández, "Kraft pulp biobleaching and mediated oxidation of a nonphenolic substrate by laccase from Streptomyces cyaneus CECT 3335," Applied and Environmental Microbiology, vol. 69, no. 4, pp. 1953-1958, 2003.

[7] N. Jimenez-Juarez, R. Roman-Miranda, A. Baeza, A. Sánchez-Amat, R. Vazquez-Duhalt, and B. Valderrama, "Alkali and halide-resistant catalysis by the multipotent oxidase from Marinomonas mediterranea," Journal of Biotechnology, vol. 117, no. 1, pp. 73-82, 2005.

[8] G. D. Thakker, C. S. Evans, and K. Koteswara Rao, "Purification and characterization of laccase from Monocillium indicum Saxena," Applied Microbiology and Biotechnology, vol. 37, no. 3, pp. 321-323, 1992.

[9] B. Viswanath, M. Subhosh Chandra, H. Pallavi, and B. Rajasekhar Reddy, "Screening and assessment of laccase producing fungi isolated from different environmental samples," African Journal of Biotechnology, vol. 7, no. 8, pp. 1129-1133, 2008.

[10] L. L. Kiiskinen, K. Kruus, M. Bailey, E. Ylösmäki, M. Siika-aho, and M. Saloheimo, "Expression of Melanocarpus albomyces laccase in Trichoderma reesei and characterization of the purified enzyme," Microbiology, vol. 150, no. 9, pp. 3065-3074, 2004.

[11] L. L. Kiiskinen, M. Rättö, and K. Kruus, "Screening for novel laccase-producing microbes," Journal of Applied Microbiology, vol. 97, no. 3, pp. 640-646, 2004.

[12] M. L. Niku-Paavola, E. Karhunen, P. Salola, and V. Raunio, "Ligninolytic enzymes of the white-rot fungus Phlebia radiata," Biochemical Journal, vol. 254, no. 3, pp. 877-884, 1988.

[13] G. Palmieri, P. Giardina, C. Bianco, B. Fontallella, and G. Sannina, "Copper induction of laccase isoenzyme in the lignolytic fungus Pleurotus ostreatus," Appl Microbiol Biotechnol, vol. 66, pp. 920-924, 2000.
[14] R. Bourbonnais, M. G. Paice, I. D. Reid, P. Lanthier, and M. Yaguchi, "Lignin oxidation by laccase isozymes from Trametes versicolorand role of the mediator 2,22' azinobis(3-ethylbenzthiazoline-6-sulfonate) in kraft lignin depolymerization," Applied and Environmental Microbiology, vol. 61, no. 5, pp. 1876-1880, 1995.

[15] U. Hölker, J. Dohse, and M. Höfer, "Extracellular laccases in ascomycetes Trichoderma atroviride and Trichoderma harzianum," Folia Microbiologica, vol. 47, no. 4, pp. 423-427, 2002.

[16] M. A. Velázquez-Cedeño, A. M. Farnet, E. Ferré, and J. M. Savoie, "Variations of lignocellulosic activities in dual cultures of Pleurotus ostreatus and Trichoderma longibrachiatum on unsterilized wheat straw," Mycologia, vol. 96, no. 4, pp. 712-719, 2004.

[17] C. Eggert, U. Temp, and K. E. L. Eriksson, "The ligninolytic system of the white rot fungus Pycnoporus cinnabarinus: purification and characterization of the laccase," Applied and Environmental Microbiology, vol. 62, no. 4, pp. 1151-1158, 1996.

[18] S. B. Pointing and L. L. P. Vrijmoed, "Decolorization of azo and triphenylmethane dyes by Pycnoporus sanguineus producing laccase as the sole phenoloxidase," World Journal of Microbiology and Biotechnology, vol. 16, no. 3, pp. 317-318, 2000.

[19] C. F. Thurston, "The structure and function of fungal laccases," Microbiology, vol. 140, no. 1, pp. 19-26, 1994.

[20] D. S. Yaver, R. M. Berka, S. H. Brown, and F. Xu, The Presymposium on Recent Advances in Lignin Biodegradation and Biosynthesis, vol. 3-4 of Vikki Biocentre, Vikki Biocentre, University of Helsinki, Helsinki, Finland, 2001.

[21] R. Bourbonnais and M. G. Paice, "Oxidation of nonphenolic substrates. An expended role for laccase in lignin biodegradation," FEBS Letters, vol. 267, no. 1, pp. 99-102, 1990.

[22] L. Quintanar, J. Yoon, C. P. Aznar et al., "Spectroscopic and electronic structure studies of the trinuclear $\mathrm{Cu}$ cluster active site of the multicopper oxidase laccase: nature of its coordination unsaturation," Journal of the American Chemical Society, vol. 127, no. 40, pp. 13832-13845, 2005.

[23] G. Zoppellaro, H. W. Huang, and T. Sakurai, "Kinetic studies on the reaction of the fully reduced laccase with dioxygen," Inorganic Reaction Mechanisms, vol. 2, pp. 79-84, 2000.

[24] V. K. Gochev and A. I. Krastanov, "Fungal laccases," Bulgarian Journal of Agricultural Science, vol. 13, pp. 75-83, 2007.

[25] H. Agematu, T. Tsuchida, K. Kominato et al., "Enzymatic dimerization of penicillin X," Journal of Antibiotics, vol. 46, no. 1, pp. 141-148, 1993.

[26] O. V. Morozova, G. P. Shumakovich, M. A. Gorbacheva, S. V. Shleev, and A. I. Yaropolov, "Blue laccases," Biochemistry (Moscow), vol. 72, no. 10, pp. 1136-1150, 2007.

[27] A. Abdel-Raheem and C. A. Shearer, "Extracellular enzyme production by freshwater ascomycetes," Fungal Diversity, vol. 11, pp. 1-19, 2002.

[28] U. C. Banerjee and R. M. Vohra, "Production of laccase by Curvularia sp," Folia Microbiologica, vol. 36, no. 4, pp. 343346, 1991.

[29] C. Junghanns, M. Moeder, G. Krauss, C. Martin, and D. Schlosser, "Degradation of the xenoestrogen nonylphenol by aquatic fungi and their laccases," Microbiology, vol. 151, no. 1, pp. 45-57, 2005.

[30] A. Rodríguez, M. A. Falcón, A. Carnicero, F. Perestelo, G. De La Fuente, and J. Trojanowski, "Laccase activities of Penicillium chrysogenum chrysogenum in relation to 
lignin degradation," Applied Microbiology and Biotechnology, vol. 45, no. 3, pp. 399-403, 1996.

[31] M. Scherer and R. Fischer, "Purification and characterization of laccase II of Aspergillus nidulans," Archives of Microbiology, vol. 170, no. 2, pp. 78-84, 1998.

[32] T. Binz and G. Canevascini, "Purification and partial characterization of the extracellular laccase from Ophiostoma novoulmi," Current Microbiology, vol. 35, no. 5, pp. 278-281, 1997.

[33] W. A. Edens, T. Q. Goins, D. Dooley, and J. M. Henson, "Purification and characterization of a secreted laccase of Gaeumannomyces graminis var. tritici," Applied and Environmental Microbiology, vol. 65, no. 7, pp. 3071-3074, 1999.

[34] S. C. Froehner and K. E. Eriksson, "Purification and properties of Neurospora crassa laccase," Journal of Bacteriology, vol. 120, no. 1, pp. 458-465, 1974.

[35] G. Iyer and B. B. Chattoo, "Purification and characterization of laccase from the rice blast fungus, Magnaporthe grisea," FEMS Microbiology Letters, vol. 227, no. 1, pp. 121-126, 2003.

[36] L. L. Kiiskinen, L. Viikari, and K. Kruus, "Purification and characterisation of a novel laccase from the ascomycete Melanocarpus albomyces," Applied Microbiology and Biotechnology, vol. 59, no. 2-3, pp. 198-204, 2002.

[37] H. P. Molitoris and K. Esser, "The phenoloxidases of the ascomycete Podospora anserina. v. Properties of laccase I after further purification," Archives of Microbiology, vol. 72, no. 3, pp. 267-296, 1970.

[38] H. Palonen, M. Saloheimo, L. Viikari, and K. Kruus, "Purification, characterization and sequence analysis of a laccase from the ascomycete Mauginiella sp," Enzyme and Microbial Technology, vol. 33, no. 6, pp. 854-862, 2003.

[39] A. F. D. Vasconcelos, A. M. Barbosa, R. F. H. Dekker, I. S. Scarminio, and M. I. Rezende, "Optimization of laccase production by Botryosphaeria sp. in the presence of veratryl alcohol by the response-surface method," Process Biochemistry, vol. 35, no. 10, pp. 1131-1138, 2000.

[40] J. I. Lyons, S. Y. Newell, A. Buchan, and M. A. Moran, “Diversity of ascomycete laccase gene sequences in a southeastern US salt marsh," Microbial Ecology, vol. 45, no. 3, pp. 270-281, 2003.

[41] C. Stoj and D. J. Kosman, "Cuprous oxidase activity of yeast Fet3p and human ceruloplasmin: implication for function," FEBS Letters, vol. 554, no. 3, pp. 422-426, 2003.

[42] A. Hatakka, "Biodegradation of lignin," in Lignin, Humic Substances and Coal, M. Hofrichter and A. Steinbuchel, Eds., pp. 129-179, Wiley-VCH, Weinheim, Germany, 2001.

[43] K. H. Lee, S. G. Wi, A. P. Singh, and Y. S. Kim, "Micromorphological characteristics of decayed wood and laccase produced by the brown-rot fungus Coniophora puteana," Journal of Wood Science, vol. 50, no. 3, pp. 281-284, 2004.

[44] D. Schlosser and C. Höfer, "Laccase-catalyzed oxidation of $\mathrm{Mn}^{2+}$ in the presence of natural $\mathrm{Mn}^{3+}$ chelators as a novel source of extracellular $\mathrm{H}_{2} \mathrm{O}_{2}$ production and its impact on manganese peroxidase," Applied and Environmental Microbiology, vol. 68, no. 7, pp. 3514-3521, 2002.

[45] R. Gayazov and J. Rodakiewicz-Nowak, "Semi-continuous production of laccase by Phlebia radiata in different culture media," Folia Microbiologica, vol. 41, no. 6, pp. 480-484, 1996.

[46] P. Keyser, T. K. Kirk, and J. G. Zeikus, "Ligninolytic enzyme system of Phanerochaete chrysosporium: synthesized in the absence of lignin in response to nitrogen starvation," Journal of Bacteriology, vol. 135, no. 3, pp. 790-797, 1978.
[47] G. F. Leatham and T. Kent Kirk, "Regulation of ligninolytic activity by nutrient nitrogen in white-rot basidiomycetes," FEMS Microbiology Letters, vol. 16, no. 1, pp. 65-67, 1983.

[48] M. C. Monteiro and M. E. A. De Carvalho, "Pulp bleaching using laccase from Trametes versacolor under high temperature and alkaline conditions," Applied Biochemistry and Biotechnology, vol. 70-72, p. 983, 1998.

[49] J. A. Buswell, Y. Cai, and S. T. Chang, "Effect of nutrient nitrogen and manganese on manganese peroxidase and laccase production by Lentinula (Lentinus) edodes," FEMS Microbiology Letters, vol. 128, no. 1, pp. 81-88, 1995.

[50] S. B. Pointing, E. B. G. Jones, and L. L. P. Vrijmoed, "Optimization of laccase production by Pycnoporus sanguineus in submerged liquid culture," Mycologia, vol. 92, no. 1, pp. 139144, 2000.

[51] A. M. Farnet, S. Criquet, S. Tagger, G. Gil, and J. Le Petit, "Purification, partial characterization, and reactivity with aromatic compounds of two laccases from Marasmius quercophilus strain 17," Canadian Journal of Microbiology, vol. 46, no. 3, pp. 189-194, 2000.

[52] G. Palmieri, P. Giardina, L. Marzullo et al., "Stability and activity of a phenol oxidase from the ligninolytic fungus Pleurotus ostreatus," Applied Microbiology and Biotechnology, vol. 39, no. 4-5, pp. 632-636, 1993.

[53] G. S. Nyanhongo, J. Gomes, G. Gübitz, R. Zvauya, J. S. Read, and W. Steiner, "Production of laccase by a newly isolated strain of Trametes modesta," Bioresource Technology, vol. 84, no. 3, pp. 259-263, 2002.

[54] A. Kunamneni, A. Ballesteros, F. J. Plou, and M. Alcalde, "Fungal laccase-a versatile enzyme for biotechnological applications," in Communicating Current Research and Educational Topics and Trends in Applied Microbiology, A. Mendez-Vilas, Ed., vol. 1, pp. 233-245, Formex, Badajoz, Spain, 2007.

[55] L. Cordi, R. C. Minussi, R. S. Freire, and N. Durán, "Fungal laccase: copper induction, semi-purification, immobilization, phenolic effluent treatment and electrochemical measurement," African Journal of Biotechnology, vol. 6, no. 10, pp. 1255-1259, 2007.

[56] M. J. Han, H. T. Choi, and H. G. Song, "Purification and characterization of laccase from the white rot fungus Trametes versicolor," Journal of Microbiology, vol. 43, no. 6, pp. 555-560, 2005.

[57] V. S. Valeriano, A. M. F. Silva, M. F. Santiago, M. T. F. Bara, and T. A. Garcia, "Production of laccase by Pycnoporus sanguineus using 2,5-xylidine and ethanol," Brazilian Journal of Microbiology, vol. 40, no. 4, pp. 790-794, 2009.

[58] J. Hess, C. Leitner, C. Galhaup et al., "Enhanced formation of extracellular laccase activity by the white-rot fungus Trametes multicolor," Applied Biochemistry and Biotechnology-Part A Enzyme Engineering and Biotechnology, vol. 98-100, pp. 229241, 2002.

[59] M. Mohorčič, J. Friedrich, and A. Pavko, "Decolourization of the diazo dye reactive black 5 by immobilised Bjerkundera adusta in a stirred tank bioreactor," Acta Chimica Slovenica, vol. 51, no. 4, pp. 619-628, 2004.

[60] A. P. M. Tavares, M. A. Z. Coelho, M. S. M. Agapito, J. A. P. Coutinho, and A. M. R. B. Xavier, "Optimization and modeling of laccase production by Trametes versicolor in a bioreactor using statistical experimental design," Applied Biochemistry and Biotechnology, vol. 134, no. 3, pp. 233-248, 2006. 
[61] M. Heinzkill, L. Bech, T. Halkier, P. Schneider, and T. Anke, "Characterization of laccases and peroxidases from woodrotting fungi (family Coprinaceae)," Applied and Environmental Microbiology, vol. 64, no. 5, pp. 1601-1606, 1998.

[62] I. Y. Lee, K. H. Jung, C. H. Lee, and Y. H. Park, "Enhanced production of laccase in Trametes vesicolor by the addition of ethanol," Biotechnology Letters, vol. 21, no. 11, pp. 965-968, 1999.

[63] A. M. R. B. Xavier, D. V. Evtuguin, R. M. P. Ferreira, and F. L. Amado, "Laccase production for lignin oxidase activity," in Proceedings of the 8th International Conference on Biotechnology, Helsinki, Finland, 2001.

[64] J. M. Bollag and A. Leonowicz, "Comparative studies of extracellular fungal laccases," Applied and Environmental Microbiology, vol. 48, no. 4, pp. 849-854, 1984.

[65] A. M. Barbosa, R. F. H. Dekker, and G. E. St. Hardy, "Veratryl alcohol as an inducer of laccase by an ascomycete, botryosphaeria sp., when screened on the polymeric dye poly R-478," Letters in Applied Microbiology, vol. 23, no. 2, pp. 93 96, 1996.

[66] V. Faraco, P. Giardina, G. Palmieri, and G. Sannia, "Metalactivated laccase promoters," Progress in Biotechnology, vol. 21, pp. 105-111, 2002.

[67] I. Robene-Soustrade and B. Lung-Escarmant, "Laccase isoenzyme patterns of European Armillaria species from culture filtrates and infected woody plant tissues," European Journal of Forest Pathology, vol. 27, no. 2, pp. 105-114, 1997.

[68] S. X. F. Lu, C. L. Jones, and G. T. Lonergan, "Correlation between fungal morphology and laccase expression under the influence of cellobiose induction," in Proceedings of the 10th International Biotechnology Symposium and 9th International Symposium on Yeasts, Sydney, Australia, 1996.

[69] A. Assavanig, B. Amornkitticharoen, N. Ekpaisal, V. Meevootisom, and T. W. Flegel, "Isolation, characterization and function of laccase from Trichoderma," Applied Microbiology and Biotechnology, vol. 38, no. 2, pp. 198-202, 1992.

[70] P. Tong, Y. Hong, Y. Xiao, M. Zhang, X. Tu, and T. Cui, "High production of laccase by a new basidiomycete," Biotechnology Letters, vol. 29, no. 2, pp. 295-301, 2007.

[71] D. D’Souza-Ticlo, D. Sharma, and C. Raghukumar, “A thermostable metal-tolerant laccase with bioremediation potential from a marine-derived fungus," Marine Biotechnology, vol. 11, no. 6, pp. 725-737, 2009.

[72] E. Dubé, F. Shareck, Y. Hurtubise, C. Daneault, and M. Beauregard, "Homologous cloning, expression, and characterisation of a laccase from Streptomyces coelicolor and enzymatic decolourisation of an indigo dye," Applied Microbiology and Biotechnology, vol. 79, no. 4, pp. 597-603, 2008.

[73] P. Blánquez, G. Caminal, M. Sarrà, and T. Vicent, "The effect of HRT on the decolourisation of the grey lanaset G textile dye by Trametes versicolor," Chemical Engineering Journal, vol. 126, no. 2-3, pp. 163-169, 2007.

[74] P. Blánquez, N. Casas, X. Font et al., "Mechanism of textile metal dye biotransformation by Trametes versicolor," Water Research, vol. 38, no. 8, pp. 2166-2172, 2004.

[75] P. Blánquez, M. Sarrà, and M. T. Vicent, "Study of the cellular retention time and the partial biomass renovation in a fungal decolourisation continuous process," Water Research, vol. 40, no. 8, pp. 1650-1656, 2006.

[76] J. M. Lema, E. Roca, A. Sanroman, M. J. Nunez, M. T. Moreira, and G. Feijoo, "Pulsating bioreactors," in Multiphase Bioreactor Design, J. M. S. Cabral, M. Mota, and J. Tramper, Eds., pp. 309-329, Taylor and Francis, London, UK, 2001.
[77] S. Romero, P. Blánquez, G. Caminal et al., "Different approaches to improving the textile dye degradation capacity of Trametes versicolor," Biochemical Engineering Journal, vol. 31, no. 1, pp. 42-47, 2006.

[78] A. K. Luke and S. G. Burton, "A novel application for Neurospora crassa: progress from batch culture to a membrane bioreactor for the bioremediation of phenols," Enzyme and Microbial Technology, vol. 29, no. 6-7, pp. 348-356, 2001.

[79] S. R. Couto, M. A. Sanromán, D. Hofer, and G. M. Gübitz, "Stainless steel sponge: a novel carrier for the immobilisation of the white-rot fungus Trametes hirsuta for decolourization of textile dyes," Bioresource Technology, vol. 95, no. 1, pp. 6772, 2004.

[80] S. R. Couto, M. A. Sanromán, D. Hofer, and G. M. Gübitz, "Production of laccase by Trametes hirsuta grown in an immersion bioreactor and its application in the decolorization of dyes from a leather factory," Engineering in Life Sciences, vol. 4, no. 3, pp. 233-238, 2004.

[81] M. R. Sedarati, T. Keshavarz, A. A. Leontievsky, and C. S. Evans, "Transformation of high concentrations of chlorophenols by the white-rot basidiomycete Trametes versicolor immobilized on nylon mesh," Electronic Journal of Biotechnology, vol. 6, no. 2, pp. 27-37, 2003.

[82] K. Brijwani, H. S. Oberoi, and P. V. Vadlani, "Production of a cellulolytic enzyme system in mixed-culture solid-state fermentation of soybean hulls supplemented with wheat bran," Process Biochemistry, vol. 45, no. 1, pp. 120-128, 2010.

[83] S. R. Couto and M. A. Sanromán, "Application of solid-state fermentation to ligninolytic enzyme production," Biochemical Engineering Journal, vol. 22, no. 3, pp. 211-219, 2005.

[84] M. Moo-Young, A. R. Moreira, and R. P. Tengerdy, "Principles of solid sate fermentation: the filamentous fungi," J. E. Smith, D. R. Berry, and B. Kristiansen, Eds., pp. 117-144, Edward Arnold, London, UK, 1983.

[85] A. Pandey, P. Selvakumar, C. R. Soccol, and P. Nigam, "Solid state fermentation for the production of industrial enzymes," Current Science, vol. 77, no. 1, pp. 149-162, 1999.

[86] S. R. Couto and J. L. Toca-Herrera, "Laccase production at reactor scale by filamentous fungi," Biotechnology Advances, vol. 25, no. 6, pp. 558-569, 2007.

[87] S. R. Couto, D. Moldes, A. Liébanas, and A. Sanromán, "Investigation of several bioreactor configurations for laccase production by Trametes versicolor operating in solid-state conditions," Biochemical Engineering Journal, vol. 15, no. 1, pp. 21-26, 2003.

[88] S. R. Couto, E. López, and M. A. Sanromán, "Utilisation of grape seeds for laccase production in solid-state fermentors," Journal of Food Engineering, vol. 74, no. 2, pp. 263-267, 2006.

[89] E. Rosales, S. R. Couto, and M. A. Sanromán, "Increased laccase production by Trametes hirsuta grown on ground orange peelings," Enzyme and Microbial Technology, vol. 40, no. 5, pp. 1286-1290, 2007.

[90] C. Muñoz, F. Guillén, A. T. Martínez, and M. J. Martínez, "Induction and characterization of laccase in the ligninolytic fungus Pleurotus eryngii," Current Microbiology, vol. 34, no. 1, pp. 1-5, 1997.

[91] M. Lorenzo, D. Moldes, S. R. Couto, and A. Sanromán, "Improving laccase production by employing different lignocellulosic wastes in submerged cultures of Trametes versicolor," Bioresource Technology, vol. 82, no. 2, pp. 109-113, 2002.

[92] S. S. Kahraman and I. H. Gurdal, "Effect of synthetic and natural culture media on laccase production by white rot 
fungi," Bioresource Technology, vol. 82, no. 3, pp. 215-217, 2002.

[93] C. Souza, A. Zilly, and R. M. Peralta, "Production of laccase as the sole phenoloxidase by a Brazilian strain of Pleurotus pulmonarius in solid state fermentation," Journal of Basic Microbiology, vol. 42, no. 2, pp. 83-90, 2002.

[94] E. Grotewold, G. E. Taccioli, G. O. Aisemberg, and N. D. Judewicz, "Purification of an extracellular fungal laccase," Mircen Journal of Applied Microbiology and Biotechnology, vol. 4, pp. 357-363, 1998.

[95] S. Khammuang and R. Sarnthima, "Laccase activity from fresh fruiting bodies of Ganoderma sp. MK05: purification and remazol brilliant blue $\mathrm{R}$ decolorization," Journal of Biological Sciences, vol. 9, no. 1, pp. 83-87, 2009.

[96] A. Domínguez, S. R. Couto, and M. A. Sanromán, "Dye decolorization by Trametes hirsuta immobilized into alginate beads," World Journal of Microbiology and Biotechnology, vol. 21, no. 4, pp. 405-409, 2005.

[97] H. Hou, J. Zhou, J. Wang, C. Du, and B. Yan, "Enhancement of laccase production by Pleurotus ostreatus and its use for the decolorization of anthraquinone dye," Process Biochemistry, vol. 39, no. 11, pp. 1415-1419, 2004.

[98] P. Blánquez, N. Casas, X. Font et al., "Mechanism of textile metal dye biotransformation by Trametes versicolor," Water Research, vol. 38, no. 8, pp. 2166-2172, 2004.

[99] J. A. Ramsay and T. Nguyen, "Decolourization of textile dyes by Trametes versicolour and its effect on dye toxicity," Biotechnology Letters, vol. 24, pp. 1757-1761, 2002.

[100] M. S. Roriz, J. F. Osma, J. A. Teixeira, and S. R. Couto, "Application of response surface methodological approach to optimise Reactive Black 5 decolouration by crude laccase from Trametes pubescens," Journal of Hazardous Materials, vol. 169, no. 1-3, pp. 691-696, 2009.

[101] A. Ünal and N. Kolankaya, "Dechlorination of bleached kraft pulp by laccase enzyme produced from some whiterot fungi," Turkish Electronic Journal of Biotechnology, vol. 25, pp. 67-72, 2001.

[102] S. Riva, "Laccases: blue enzymes for green chemistry," Trends in Biotechnology, vol. 24, no. 5, pp. 219-226, 2006.

[103] A. C. Bastos and N. Magan, "Trametes versicolor: potential for atrazine bioremediation in calcareous clay soil, under low water availability conditions," International Biodeterioration and Biodegradation, vol. 63, no. 4, pp. 389-394, 2009.

[104] Y. S. Keum and Q. X. Li, "Fungal laccase-catalyzed degradation of hydroxy polychlorinated biphenyls," Chemosphere, vol. 56, no. 1, pp. 23-30, 2004.

[105] C. Udayasoorian and P. C. Prabu, "Biodegradation of phenols by lignolytic fungus Trametes versicolour," Journal of Biological Sciences, vol. 5, pp. 824-827, 2005.

[106] M. Y. Ahn, J. Dec, J. E. Kim, and J. M. Bollag, "Treatment of 2,4-dichlorophenol polluted soil with free and immobilized laccase," Journal of Environmental Quality, vol. 31, no. 5, pp. 1509-1515, 2002.

[107] V. Madhavi and S. S. Lele, "Laccase: properties and applications," BioResources, vol. 4, no. 4, pp. 1694-1717, 2009.

[108] T. E. Mathiasen, "Laccase and beer storage," PCT international application, WO 9521240 A2, 1995.

[109] R. C. Minussi, G. M. Pastore, and N. Durán, "Potential applications of laccase in the food industry," Trends in Food Science and Technology, vol. 13, no. 6-7, pp. 205-216, 2002.

[110] D. S. Ribeiro, S. M.B. Henrique, L. S. Oliveira, G. A. Macedo, and L. F. Fleuri, "Enzymes in juice processing: a review," International Journal of Food Science and Technology, vol. 45, no. 4, pp. 635-641, 2010.
[111] R. C. Minussi, M. Rossi, L. Bologna, D. Rotilio, G. M. Pastore, and N. Durán, "Phenols removal in musts: strategy for wine stabilization by laccase," Journal of Molecular Catalysis B: Enzymatic, vol. 45, no. 3-4, pp. 102-107, 2007.

[112] P. K. Thassitou and I. S. Arvanitoyannis, "Bioremediation: a novel approach to food waste management," Trends in Food Science and Technology, vol. 12, no. 5-6, pp. 185-196, 2001.

[113] S. Yagüe, M. C. Terrón, T. González et al., "Biotreatment of tannin-rich beer-factory wastewater with white-rot basidiomycete coriolopsis gallica monitored by pyrolysis/gas chromatography/mass spectrometry," Rapid Communications in Mass Spectrometry, vol. 14, no. 10, pp. 905-910, 2000.

[114] T. González, M. C. Terrón, S. Yagüe, E. Zapico, G. C. Galletti, and A. E. González, "Pyrolysis/gas chromatography/mass spectrometry monitoring of fungal-biotreated distillery wastewater using Trametes sp. I-62 (CECT 20197)," Rapid Communications in Mass Spectrometry, vol. 14, no. 15, pp. 1417-1424, 2000.

[115] J. Karam and J. A. Nicell, "Potential applications of enzymes in waste treatment," Journal of Chemical Technology and Biotechnology, vol. 69, no. 2, pp. 141-153, 1997.

[116] B. R. Thomas, M. Yonekura, T. D. Morgan, T. H. Czapla, T. L. Hopkins, and K. J. Kramer, "A trypsin-solubilized laccase from pharate pupal integument of the tobacco hornworm, Manduca sexta," Insect Biochemistry, vol. 19, no. 7, pp. 611622, 1989.

[117] H. I. Yamazaki, "Cuticular phenoloxidase from the silkworm, bombyx mori: properties, solubilization, and purification," Insect Biochemistry, vol. 2, no. 8, pp. 431-444, 1972.

[118] S. O. Andersen, M. G. Peter, and P. Roepstorff, "Cuticular sclerotization in insects," Comparative Biochemistry and Physiology, vol. 113, no. 4, pp. 689-705, 1996.

[119] M. Sugumaran, L. Giglio, H. Kundzicz, S. Saul, and V. Semensi, "Studies on the enzymes involved in puparial cuticle sclerotization in Drosophila melanogaster," Archives of insect biochemistry and physiology, vol. 19, no. 4, pp. 271-283, 1992.

[120] Y. Arakane, S. Muthukrishnan, R. W. Beeman, M. R. Kanost, and K. J. Kramer, "Laccase 2 is the phenoloxidase gene required for beetle cuticle tanning," Proceedings of The National Academy of Sciences of the United States of America, vol. 102, no. 32, pp. 11337-11342, 2005.

[121] N. T. Dittmer, R. J. Suderman, H. Jiang et al., "Characterization of cDNAs encoding putative laccase-like multicopper oxidases and developmental expression in the tobacco hornworm, manduca sexta, and the malaria mosquito, anopheles gambiae," Insect Biochemistry and Molecular Biology, vol. 34, no. 1, pp. 29-41, 2004.

[122] M. Elias-Neto, M. P. M. Soares, Z. L. P. Simões, K. Hartfelder, and M. M. G. Bitondi, "Developmental characterization, function and regulation of a Laccase 2 encoding gene in the honey bee, apis mellifera (Hymenoptera, Apinae)," Insect Biochemistry and Molecular Biology, vol. 40, no. 3, pp. 241251, 2010.

[123] B. L. Niu, W. F. Shen, Y. Liu et al., "Cloning and RNAimediated functional characterization of MaLac2 of the pine sawyer, Monochamus alternatus," Insect Molecular Biology, vol. 17, no. 3, pp. 303-312, 2008.

[124] N. M. Parkinson, C. M. Conyers, J. N. Keen, A. D. MacNicoll, I. Smith, and R. J. Weaver, "cDNAs encoding large venom proteins from the parasitoid wasp Pimpla hypochondriaca identified by random sequence analysis," Comparative Biochemistry and Physiology, vol. 134, no. 4, pp. 513-520, 2003. 
[125] N. T. Dittmer and M. R. Kanost, "Insect multicopper oxidases: diversity, properties, and physiological roles," Insect Biochemistry and Molecular Biology, vol. 40, no. 3, pp. 179188, 2010.

[126] M. Hattori, K. Tsuchihara, H. Noda et al., "Molecular characterization and expression of laccase genes in the salivary glands of the green rice leafhopper, Nephotettix cincticeps (Hemiptera: Cicadellidae)," Insect Biochemistry and Molecular Biology, vol. 40, no. 4, pp. 331-338, 2010.

[127] M. J. Gorman, N. T. Dittmer, J. L. Marshall, and M. R. Kanost, "Characterization of the multicopper oxidase gene family in Anopheles gambiae," Insect Biochemistry and Molecular Biology, vol. 38, no. 9, pp. 817-824, 2008.

[128] M. Hattori, H. Konishi, Y. Tamura, K. Konno, and K. Sogawa, "Laccase-type phenoloxidase in salivary glands and watery saliva of the green rice leafhopper, Nephotettix cincticeps," Journal of Insect Physiology, vol. 51, no. 12, pp. 1359-1365, 2005.

[129] K. Sogawa, "Studies of the salivary glands of rice leafhoppers. III. Salivary phenolase," Appl. Entomol. Zool., vol. 3, pp. 1325, 1968.

[130] P. Peralta-Zamora, C. M. Pereira, E. R. L. Tiburtius et al., "Decolorization of reactive dyes by immobilized laccase," Applied Catalysis B, vol. 42, no. 2, pp. 131-144, 2003.

[131] R. C. Minussi, M. A. Miranda, J. A. Silva et al., "Purification, characterization and application of laccase from Trametes versicolor for colour and phenolic removal of olive mill wastewater in the presence of 1-hydroxybenzotriazole," African Journal of Biotechnology, vol. 6, no. 10, pp. 12481254, 2007.

[132] K. M. Alimin Abdul and M. S. M. Annuar, "Novel application of coconut husk as growth support matrix and natural inducer of fungal laccase production in a bubble column reactor," Asia-Pacific Journal of Molecular Biology and Biotechnology, vol. 17, no. 2, pp. 47-52, 2009. 

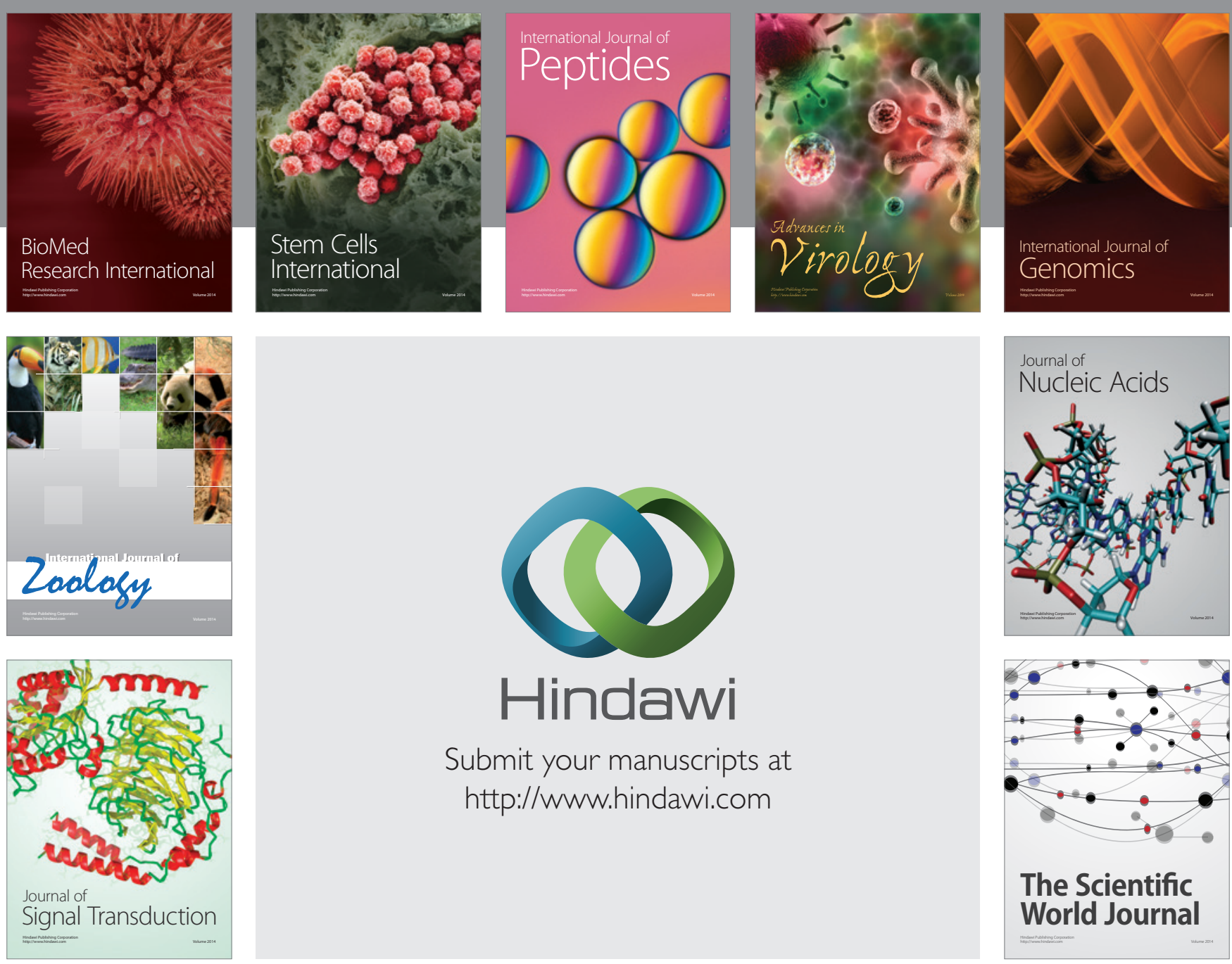

Submit your manuscripts at

http://www.hindawi.com
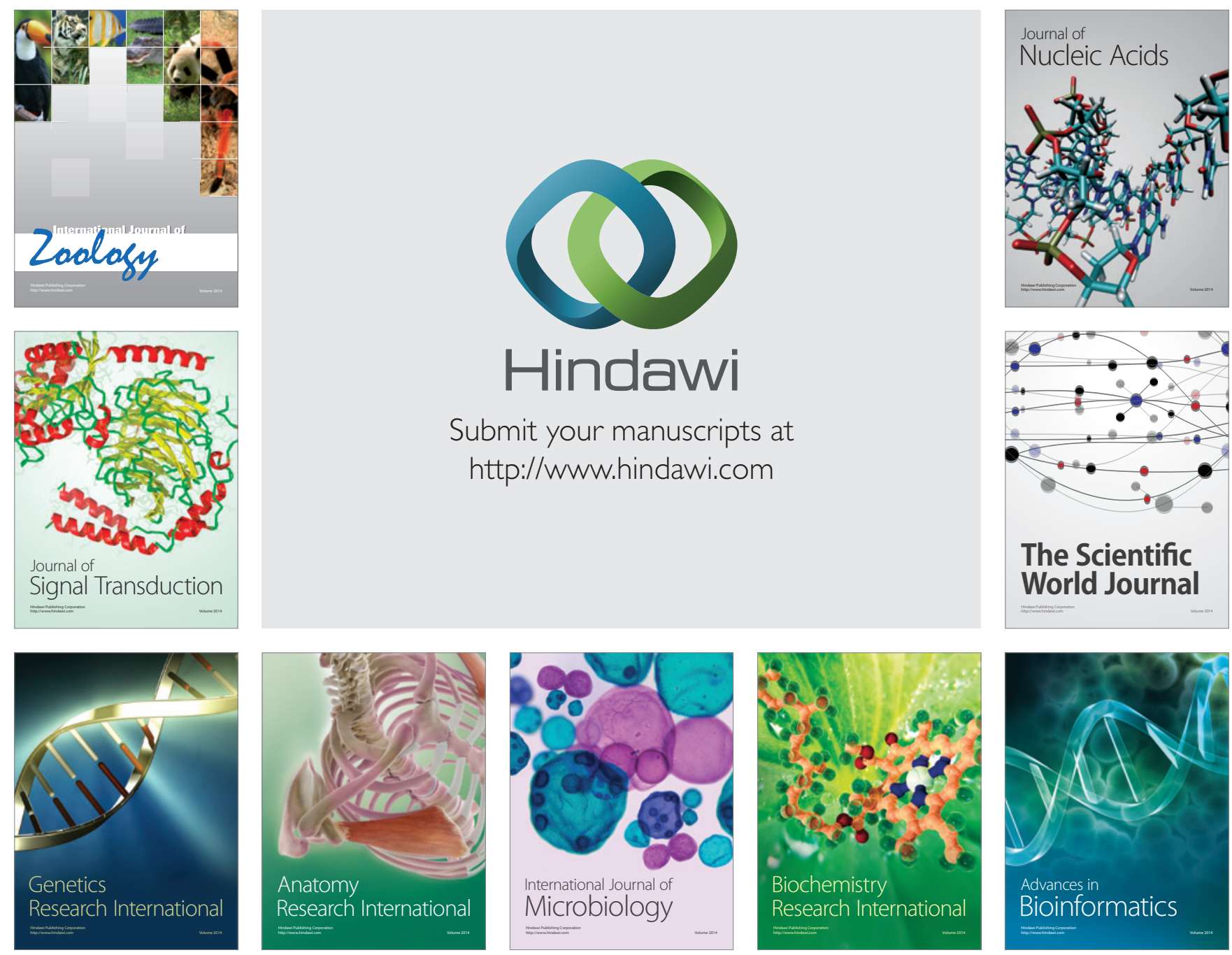

The Scientific World Journal
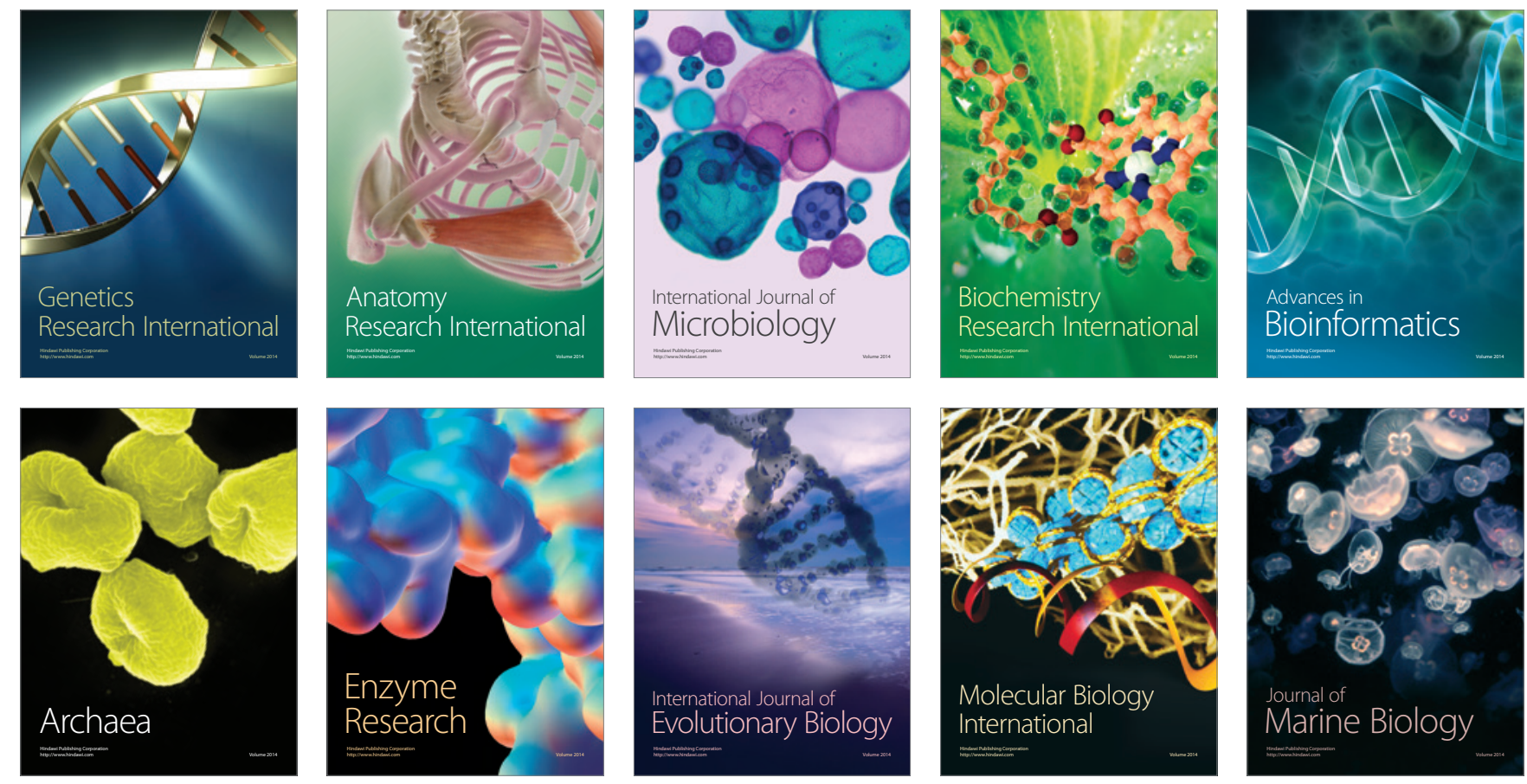